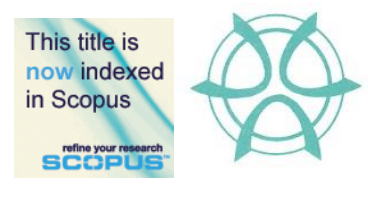

PLANNING MALAYSIA:

Journal of the Malaysian Institute of Planners

VOLUME 16 ISSUE 2 (2018), Page 225 - 235

\title{
FACTORS AFFECTING HOUSING PRICES IN MALAYSIA: ANALYSIS OF THE SUPPLY SIDE
}

\author{
AbdulLateef Olanrewaju ${ }^{1}$, Xin Ying Lim ${ }^{2}$, Seong Yeow Tan ${ }^{3}$, Jia En Lee ${ }^{4}$, \\ \& Hamimah Adnan 5 \\ 1,2,3,4 Faculty of Engineering and Green Technology \\ UNIVERSITI TUNKU ABDUL RAHMAN MALAYSIA \\ ${ }^{5}$ Faculty of Architecture, Planning and Surveying \\ UNIVERSITI TEKNOLOGI MARA, MALAYSIA
}

\begin{abstract}
Buying a house is a major decision that homebuyers will make because expenditure on homeownership has an influence on the homeowner's quality of life. The housing price also influence developers' revenues and profit margins. Developers produce houses to make profits, however, with the increase in housing prices, homeownership rate and developers' profit performance will be affected. This study examines the reasons why housing prices are increasing in spite of the government's 'cooling' measures. Through a cross-sectional survey questionnaire, comprising 24 causes and 115 members of the housing developers and designers teams, 13 influential factors to the increase in housing prices were found. Additionally, the participants were also inquired on the five most influential factors causing the increase in housing prices. The factors include the shortage of materials, quality of materials, strategic factors, housing location and availability of transportation system. The results of the study are useful to developers, homebuyers and policymakers towards reducing housing prices.
\end{abstract}

Keywords: design deficiencies, new buildings, maintenance, obsolence, housing 
AbdulLateef Olanrewaju, Xin Ying Lim, Seong Yeow Tan, Jia En Lee \& Hamimah Adnan

Factors Affecting Housing Prices in Malaysia: Analysis of The Supply Side

\section{INTRODUCTION}

The demand for housing in Malaysia will increase as there is a positive correlation between housing performance and occupants' productivity, safety, well-being and satisfaction. As Olanrewaju and Woon (2017) explained, if housing location and cost fulfill users satisfaction, the government and public sector would spend less on the provision of healthcare facilities, recreations, crime preventions and pollutions, while productivity and prosperity increase. The ability to own a house is seen as an investment in most part of the world. People spend more than 50\% of their productive time in their house. Expenditures on housing is high and for those who buy or build their houses, the property represent the single most expensive investment they make and for those that rent, the rental is often their single highest monthly or annual expenditure. Housing serves as both capital and consumption goods. Housing construction contributes significantly to the GDP in most countries. However, because the demand and supply of the housing market is uncertain, the decisions of homebuyers and the developers have strong impacts on the housing supply.

In most part of the world including the UK, the US, Japan, Hong Kong, Malaysia, Singapore, Australia, Ireland, and New Zealand, Nigeria, Indonesia and South Africa, housing is unaffordable (Demographia, 2017; Osman, Bachok, Shuid, \& Khalid, 2017a). In most countries, households spent more than $30 \%$ of their disposable income to own or rent and operate a house or the price-to-income ratio is more than 3.0. Based on the Demographia, a ratio of more than 3.0 implies housing unaffordability. However, governments across the world have introduced measures and policies to increase the quality and quantity of housing supply in order to increase homeownership and increase the quality of life. In Malaysia, while homeowners' rate is decreasing at $1 \%$ annually, the unsold residential property and overhangs are increasing (Osman, Mohamad Yusop, Shud, \& Abdullah, 2017b) To illustrate, the volume of transaction are 272,669, 246,225, 247,251 and 235,967 from year 2012 to year 2015 (NAPIC, 2015). The vacancy rate has increased from 6\% in year 2010 to more than $10 \%$ in year 2015. MIER's Residential Property Survey Report conducted in 4Q 2015 found that 70\% of the developers reported poor sales (REHDA, 2016) and many are homeless.

Academic literature leads to the conclusion that the major reason is that Malaysian housing prices are too high and has outpaced the increase in incomes and inflation (REHDA, 2016; KRI, 2015; "Loan criteria won't resolve", 2017). Various studies revealed that housings in Malaysia are 'severely unaffordable' or buyers are 'cost overburden' (Olanrewaju \& Woon, 2017; KRI, 2015; "Loan criteria won't resolve", 2017; Demographia, 2017, Osman et al., 2017a; Osman et al., 2017b). Housing is severely unaffordable if the housing price to household income ratio exceeds 5.1 (Demographia, 2017). In a study conducted by Olanrewaju, Tat, Tan, Naoto and Abdul Aziz (2016), and Osman, Rabe, Abdullah, Rosl and Zainudin (2017c), they reported that most households in 
PLANNING MALAYSIA

Journal of the Malaysia Institute of Planners (2018)

Malaysia spent more than $30 \%$ of income to own or rent and operate their houses. In terms of index, the house prices have increased by 1.86 from 2009 to 2016 while that of the high rise is more severe with increase of 2.12 within the same period (NAPIC, 2017). Therefore, there is a need to provide an answer to why housing prices are increasing in Malaysia. There are multiple reasons responsible for the increase in the housing prices. A part of the problems could be accountable to developers, contractors, government policies, and third-party agencies. In this study, the causes of the increase are examined from the supply side perspectives. Empirical research that specifically address itself to causes of increase in housing prices from the experience of the providers (i.e. developers, design team, construction team and government) is lacking. It is important to investigate housing prices from the experience of the housing providers because housing is conceptualised, designed, constructed and sometimes operated by them. The housing providers know the operation of the housing market, and how they relate to government, third-party agencies and the homebuyers.

\section{CONCEPTUAL JUSTIFICATIONS}

Housing is required to provide safety, security, protection, comfort, experience, satisfaction, and convenient to the home occupants. However, Malaysia is facing housing shortage problems, with a population of 31 million people (DOS, 2017) and 7.2 million housing stocks (DOS, 2014). There are fewer than 250 housing units per 1000 population. In order to increase the housing stocks and homeowners, the government have introduced many measures including schemes, programmes, and policies. These measures include MyHome, Perumahan Rakyat 1Malaysia (PR1MA), Rumah Mesra Rakyat (RMR1M), Program Rumah Mampu Milik (RMM), Program Penyelenggaraan 1Malaysia (TP1M), MyDeposit Scheme, Housing Loan Scheme, People's Housing Programme, Rumah Transit or transit house programme and MyBeautiful New Home. Similarly, subsidies and tax reliefs have been provided to homebuyers, developers and contractors. The government has relaxed its regulation on the EPF (Employee Prudential Fund) to enable contributors to use part of the savings as down payment for their housing loans. Developers offer discounts and split payments to home buyers. The developers (i.e. REHDA) also offer 'bridging' loan to home buyers because of the reduction in loan approval rate. The bureaucracies on land allocations are easing and the government has exempted construction property from the GST (Goods and Services Tax) and the restriction on the employment of foreign labour on contractors has been lifted. Meanwhile the housing turnover, neighbourhood instability, unsold and overhangs and dissatisfactions are high and increasing (Olanrewaju \& Woon, 2017). The size of unsold property stood at $41 \%$ in 2015 and more than $22 \%$ of the housing property was overhang in 2015 (NAPIC, 2014-2015). Table 1 contains the price indices for the last eight years, where it can be seen that housing prices are increasing. 
AbdulLateef Olanrewaju, Xin Ying Lim, Seong Yeow Tan, Jia En Lee \& Hamimah Adnan

Factors Affecting Housing Prices in Malaysia: Analysis of The Supply Side

While income has increased by approximately $101 \%$ since 1999, housing prices have increased by more than $200 \%$ within the same period (Table 2). While the private final consumption stood at RM556.6 billion in 2015, housing operations constitute the largest part of the private consumptions (DOS, 2016). The implication of this is that for Malaysians to have a decent home, they will have to cut down expenditure on food, health, social life, entertainments, and education. While the consumer index for all major items dropped from 3.2 in 2011 to 2.1 in 2015, that of housing and its operations increase from 1.8 to 2.5 within the same period.

Table 1: The Malaysian Average House Price by House Type, 2009-2016

\begin{tabular}{cccccc}
\hline Year & All house & Terraced & High rise & Detached & $\begin{array}{c}\text { Semi } \\
\text { detached }\end{array}$ \\
\hline 2009 & 204,470 & 176,413 & 161,863 & 364,424 & 354,540 \\
2010 & 215,678 & 185,505 & 172,651 & 382,512 & 374,697 \\
2011 & 239,295 & 207,702 & 192,852 & 402,124 & 417,563 \\
2012 & 271,384 & 234,934 & 223,735 & 454,186 & 465,612 \\
2013 & 301,964 & 256,910 & 254,115 & 516,750 & 522,062 \\
2014 & 330,428 & 284,136 & 277,729 & 565,869 & 554,402 \\
2015 & 354,741 & 303,826 & 299,182 & 601,785 & 591,575 \\
2016 & 379,843 & 326,445 & 326,204 & 642,775 & 619,767 \\
\hline Source: $N A P I C(2017)$ & & & &
\end{tabular}

Table 2 Annual House Price Index and house price1999-2014

\begin{tabular}{cccc}
\hline Year & Index $(2000=100$ & 1-Yr \% Change & Household income \\
\hline 2000 & 100 & - & - \\
2001 & 101.1 & 6 & - \\
2002 & 103.6 & 1.1 & 2,049 \\
2003 & 107.7 & 2.5 & - \\
2004 & 112.9 & 4 & 2,211 \\
2005 & 115.6 & 4.8 & - \\
2006 & 117.8 & 2.4 & - \\
2007 & 124 & 1.9 & 2,552 \\
2008 & 129.8 & 5.3 & \\
2009 & 131.8 & 4.7 & \\
2010 & 140.7 & 1.5 & \\
2011 & 154.6 & 6.7 & 3,626 \\
2012 & 172.8 & 9.9 & \\
2013 & 192.9 & 11.8 & 4,585 \\
2014 & 213.6 & 11.6 & \\
2015 & 236.2 & 7.3 & \\
\hline
\end{tabular}

Source: NAPIC (2017; 2014) 
PLANNING MALAYSIA

Journal of the Malaysia Institute of Planners (2018)

Thus, the policy question is what is the cause of the increase in the price of housing? The increase in housing is leaving many homeless and many are living in deplorable conditions. Although the increase in the housing prices can be examined from multiple stakeholders, this current study focused on the supply side including the contractors, developers, government agencies and the design teams. Increase in housing price would affect government policies, citizens' productivity and well-being. It would affect developers and contractors profit margins and revenues. Collectively academic literature suggests housing prices could increase because of many factors including, materials, location, interest rate, neighbourhood, social capital, lack of recreational facilities and transportation (Olanrewaju \& Woon, 2017; Olanrewaju et al., 2016; Ying, Olanrewaju, \& Tan, 2015; UN-HABITAT, 2011; Ong \& Chang, 2013; Osman et al., 2017d). Although many studies have been conducted on housing prices, empirical studies on the causes based on developers and contractors experience are nascent or inconclusive.

\section{OUTLINE OF THE RESEARCH METHOD}

The survey was conducted in two phases which were through hand delivery and online survey. The first phase was administered to the respondents that attended the ARCHIDEX (International Architecture, Interior Design \& Building Exhibition 2016) in the Kuala Lumpur Convention Centre using convenience sampling. ARCHIDEX is held annually and attended mostly by architects and other stakeholders in the construction sectors (i.e. engineers, quantity surveyors, developers, contractors) in Malaysia and around the South East Asian countries. The ARCHIDEX 2016 was held on 20 July 2016 to 23 July 2016 and attended by more than 3,000 delegates and exhibitors. This survey was conducted on $23^{\text {rd }}$ (Saturday) July 2016. 96 completed survey forms were returned. The second phase was conducted through online Google survey form from November 2017 to December 2017. Respondents from the online survey were recommended to help forward the form to their colleagues that are competent to provide valid responses. By the cut-off date, which was four weeks after the online survey was first launched, 19 valid forms were returned. The factors leading to the increase in housing prices from literature (Olanrewaju \& Woon, 2017; Olanrewaju et al., 2016; Ying et al., 2015; UN-HABITAT, 2011; Ong \& Chang, 2013; Pillaiyan, 2015; Knight Frank, 2015) and the authors' experiences were included in the survey form.

\section{RESULTS AND DISCUSSION}

\section{Respondents' profile}

Altogether 115 valid survey forms were received and used for this study. $84 \%$ of the respondents have bachelor degree and postgraduate education. In terms of 
AbdulLateef Olanrewaju, Xin Ying Lim, Seong Yeow Tan, Jia En Lee \& Hamimah Adnan Factors Affecting Housing Prices in Malaysia: Analysis of The Supply Side

their job positions, $36 \%$ of the respondents were architects, $9 \%$ was chief executive officers, and $12 \%$ were directors and managers. In terms of professional background, the majority (60\%) were architects followed by engineers $(12.2 \%)$ and quantity surveyors $(5.2 \%)$. Most of the respondents worked for private organisations and about $60 \%$ had more than 5 year working experience (Table 3 ). Private firm implies (i.e. architectural, engineering, quantity surveying consulting firm) consultant companies. About $10 \%$ specifically worked for developers. 55\% of the respondents were involved in affordable housing design and construction. Almost all the respondents had memberships in Board of Architect Malaysia, Board of Surveyor Malaysia or REHDA.

Table 3 Cross-tabulation between working experience and organisation

\begin{tabular}{cccccc}
\hline $\begin{array}{c}\text { Experience } \\
\text { Organisation }\end{array}$ & Less than 5 years & $5-10$ years & $10-15$ years & $15-20$ years & $\begin{array}{c}\text { More than } 20 \\
\text { years }\end{array}$ \\
\hline Government & 3 & 1 & 0 & 0 & 0 \\
Private Firm & 38 & 14 & 5 & 6 & 17 \\
Contractor & 2 & 0 & 1 & 0 & 0 \\
Developer & 3 & 4 & 2 & 1 & 2 \\
Supplier & 0 & 2 & 5 & 2 & 0 \\
Consultancy Firm & 3 & 1 & 0 & 1 & 2 \\
\hline Total & 49 & 22 & 13 & 10 & 21 \\
\hline
\end{tabular}

\section{Analysing the Major Causes of Increase in Housing Price}

In order to test the measures of goodness of the factors causing the increase in housing prices, Cronbach's alpha reliability and validity tests were performed. The reliability and validity tests indicated that the factors were suitable for the aim of this research (Table 4). To further confirm the strength of the data, Bartlett's test was conducted, the results showed a lack of multicollinearity among the factors and that the respondents were drawn from those with similar experiences $\left(\chi^{2}(210)=1423.511, \mathrm{p}<0.001\right)$. The KMO is 0.720 and the R-matrix is $1.323 \mathrm{E}-006$. The R-matrix indicated a lack of multicollinearity, hence adequacies of the data were justified. One sample t-test was computed to determine the hypothesis that each of the factors would lead to an increase in housing prices. For this reason, the null hypothesis was that the factor would not cause increased in housing price $\left(\mathrm{H}_{0}: \mathrm{U}=\mathrm{U}_{0}\right)$ and the research hypothesis was that the factors would cause an increase in housing price $\left(\mathrm{Hr}: \mathrm{U}>\mathrm{U}_{0}\right)$. $\mathrm{U}_{0}$ was the population mean. The comparison standard mean or critical level off point was set at 1.5. Table 5 contains the results of the t-test, where it was found that (i.e. $\operatorname{Pr}>|t|)$ of each of the causes $\left(\mathrm{H}_{\mathrm{r}}: \mathrm{U}>\mathrm{U}_{0}\right)$ were significant. The small standard errors, being nearer to zero suggested that the measurements of the respondents with respect to the factors were representative. All the factors were statically 
significant. Therefore, all the factors were adequate and suitable to be included in the survey to achieve the aim of the research.

The profile of the respondents is not discussed further, and only 13 main factors leading to the increase in housing price are briefly discussed after general discussions of the results are provided. Considering the relationship between the mean and standard deviation, the results interpreted that more than $70 \%$ of the respondents measured the factors that would increase prices of houses. In fact, the percentage of the respondents that disagreed or strongly disagreed was $27.52 \%$. Exactly $42.35 \%$ agreed and strongly agreed to the ratings. $32.13 \%$ slightly agreed. It is also obvious that 13 of the factors were the most influential for estimating housing prices. Location was considered as the factor that had the highest influence on the housing price according to the entire respondents. $88 \%$ of the respondents indicated that the housing location had the highest impact on housing price. This result was expected because the price of lands and the associated costs related to land were varied extensively. Lands in the cities were very expensive compared to lands outside the cities. Regulations on lands and construction in the cities were also very strict, especially for affordable housing. It was also not surprising that the respondents rated the size of the house as the second most influential factor for housing price. This was because costs of construction were actually determined by the size of the house. For instance, in Malaysia, housing was priced at RM1, 200/ $\mathrm{m}^{2}$ in Kuala Lumpur. It was interesting to discover that innovation and skills were considered as the next most influencing factor on housing prices. This was not expected, however, construction costs were significantly influenced by the level of technology employed by the developers and construction on site. For instance, consultants' fees, claims and delay can also be reduced by using software like BIM.

Table 4: Distribution of ranking of factors leading to housing price

\begin{tabular}{|c|c|c|c|c|c|c|c|c|c|}
\hline 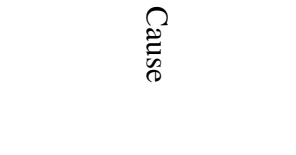 & 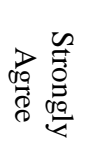 & 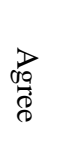 & 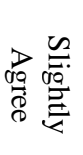 & 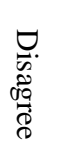 & 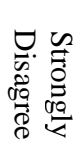 & 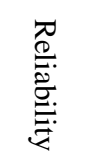 & 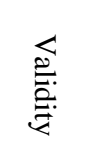 & 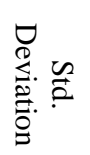 & 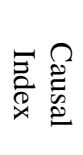 \\
\hline Location - urban/rural & 18 & 83 & 12 & 2 & 0 & 0.809 & 0.754 & 0.577 & 1.983 \\
\hline Size of the house & 10 & 56 & 48 & 1 & 0 & 0.809 & 0.728 & 0.649 & 2.348 \\
\hline Innovation and skills & 11 & 61 & 35 & 7 & 1 & 0.813 & 0.798 & 0.774 & 2.357 \\
\hline $\begin{array}{l}\text { Developers' profit } \\
\text { margin }\end{array}$ & 12 & 63 & 28 & 10 & 2 & 0.814 & 0.793 & 0.852 & 2.365 \\
\hline Strategic factors & 2 & 63 & 46 & 4 & 0 & 0.807 & 0.604 & 0.596 & 2.452 \\
\hline Shortage of material & 7 & 66 & 24 & 16 & 2 & 0.813 & 0.730 & 0.872 & 2.478 \\
\hline
\end{tabular}


AbdulLateef Olanrewaju, Xin Ying Lim, Seong Yeow Tan, Jia En Lee \& Hamimah Adnan Factors Affecting Housing Prices in Malaysia: Analysis of The Supply Side

\begin{tabular}{|l|c|c|c|c|c|c|c|c|c|} 
Rising labour costs & 14 & 40 & 24 & 37 & 0 & 0.791 & 0.871 & 1.046 & 2.730 \\
\hline $\begin{array}{l}\text { Economic uncertainty } \\
\text { and financial risks }\end{array}$ & 13 & 40 & 27 & 35 & 0 & 0.794 & 0.884 & 1.020 & 2.730 \\
\hline $\begin{array}{l}\text { Planning restriction on } \\
\text { the use of land }\end{array}$ & 6 & 24 & 79 & 5 & 1 & 0.802 & 0.758 & 0.660 & 2.748 \\
\hline $\begin{array}{l}\text { Quality of material \& } \\
\text { component use }\end{array}$ & 6 & 30 & 65 & 13 & 1 & 0.806 & 0.682 & 0.753 & 2.765 \\
\hline $\begin{array}{l}\text { Leasehold / freehold } \\
\text { house }\end{array}$ & 0 & 54 & 33 & 28 & 0 & 0.796 & 0.829 & 0.817 & 2.774 \\
\hline Climate changes & 0 & 55 & 32 & 25 & 3 & 0.825 & 0.774 & 0.874 & 2.791 \\
\hline Interest rates & 9 & 35 & 41 & 30 & 0 & 0.800 & 0.589 & 0.920 & 2.800 \\
\hline $\begin{array}{l}\text { Households confidence } \\
\text { on future price }\end{array}$ & 12 & 38 & 23 & 42 & 0 & 0.807 & 0.623 & 1.045 & 2.826 \\
\hline $\begin{array}{l}\text { Number of new houses } \\
\text { being built }\end{array}$ & 3 & 28 & 62 & 22 & 0 & 0.804 & 0.734 & 0.730 & 2.896 \\
\hline Geographical factors & 3 & 41 & 32 & 39 & 0 & 0.798 & 0.847 & 0.896 & 2.930 \\
\hline $\begin{array}{l}\text { Availability of facilities } \\
\text { [eg: swimming pool, } \\
\text { gym room, basketball } \\
\text { field, playground \& } \\
\text { etc.)] }\end{array}$ & 13 & 25 & 29 & 44 & 4 & 0.804 & 0.844 & 1.096 & 3.009 \\
\hline Layout of the house & 3 & 29 & 29 & 26 & 28 & 0.792 & 0.883 & 1.184 & 3.409 \\
\hline Stamp duty & 5 & 18 & 38 & 25 & 29 & 0.793 & 0.877 & 1.157 & 3.478 \\
\hline Currency exchange rate & 8 & 24 & 23 & 24 & 36 & 0.791 & 0.741 & 1.314 & 3.487 \\
\hline Permit fees & 3 & 17 & 38 & 28 & 29 & 0.793 & 0.891 & 1.102 & 3.548 \\
\hline
\end{tabular}

The developer's profits were also rated as a major factor that would cause the price of a house to increase and reduce. This was interesting and the findingwas not surprising because previous research reported that the profit margin of Malaysian developers was very high at around 20\% (Ying et al., 2015). Strategic factor, marked by the proximity of the housing to schools, hospitals, place of works, and the market was also rated to be a major determinant of housing prices. This was expected because housings that were close to schools, markets, and workplaces were preferable to homebuyers, for strategic reasons including a reduction in the cost of transports because of accessibility, conformability and conveniences reasons.

Material cost constituted about $60 \%$ of housing construction prices. Therefore, shortage and the associated increase in the cost of materials would have the significant impact on the housing price. Hence, it was not surprising that shortage or availability of materials was rated as an important factor in the estimation of housing price. It was interesting that the respondents also indicated that the labour cost would increase housing price. 
PLANNING MALAYSIA

Journal of the Malaysia Institute of Planners (2018)

The housing industry was labour intensive and most of the sites operatives were from the neighbouring countries. With government regulations on foreign labour, some projects were already been impacted. Economic uncertainty and financial risks were also measured as an influential contribution to housing price.

The profit margins of developers and contractors depend on the economic situations in a country especially due to imported goods and materials. Developers tend to reduce their investment in order to reduce their exposure to financial risks. Construction business involved large investments and as a result the developers also depend on loan from the banks. During recession, most businesses including housing developers would reduce their activities to reduce loss.

As previously stated, prices of lands had the most influential impact on the housing price. Therefore, restriction on the use of the land would undoubtedly upset the cost of construction and ultimately the price of the completed housing. Quality of materials was also found to make dominant bearing on the prices of houses. This was not surprising because the quality of materials determined housing production costs like any other goods and services in the marketplaces. The type of land ownership was also recognized as major factor influencing the prices of houses. This finding was not very surprising because leaseholders would not only have to worry about the grant rent on the land, but the land would be reverted back to freeholder on the expiration of the tenure. The result was consistent with literature.

The respondents also indicated that climate change would affect housing price. This finding was not difficult to agree with as heavy rainfalls, floods, mudslides are gradually becoming part of homebuyers' checklist in Malaysia. Homebuyers are demanding for houses that would be résistance to impact of earthquakes, landslides, and mudslides especially those at the hill-sides (Olanrewaju, Tan, Tat, \& Mine, 2017). Without argument, interest rates had a significant impact on the cost of home production. Technically developers and contractors would transfer the amount they paid as interest to the homebuyers and this would, in turn, led to increase in the housing prices.

\section{CONCLUSION AND RECOMMENDATIONS TO THE HOUSING PROVIDERS}

Meeting the housing need has been the primary agenda of the government. However, achieving this aim has been significantly difficult. More than $90 \%$ of the households cannot afford houses in the current situation without some assistance. Many ongoing houses projects are abandoned and the rate of overhang and unsold properties are high. This study provides an insight into the determinants of housing prices. This study has found the 13 main causal factors for the increase in housing price. The practical implications of the findings 
AbdulLateef Olanrewaju, Xin Ying Lim, Seong Yeow Tan, Jia En Lee \& Hamimah Adnan

Factors Affecting Housing Prices in Malaysia: Analysis of The Supply Side

reported is that the government need to lessen the regulations and control on lands in order to increase homeowners and also to reduce authorities' development charges. The developers also need to reduce their profit margin expectations through proper risk assessment and reduction. Future studies on similar topic should increase the sample size and examine the practical measures to reduce housing prices. Also, future research should investigate the relationships between the causes of increase in housing prices and the causal factors and examine the association among the factors. The ranking of the factors alone would not be able to provide structural advice to place managers, developers, urban planners and policymakers.

\section{ACKNOWLEDGEMENT}

The research presented in this paper was supported in full by a grant from the "FRGS"; project: Analytical Investigation of Problems in Housing Supply in Malaysia. Project number: FRGS/1/2015/TK06/UTAR/02/2.

\section{REFERENCES}

Department of Statistics [DOS] (2014). Report on characteristics of household 2010: Population and housing census of Malaysia. Available at https://www.statistics.gov.my

Department of Statistics [DOS] (2016). Macro-economic key data at current prices. Available at www.statistics.gov.my

Department of Statistics [DOS] (2017). Current population estimates, Malaysia, 20162017. Available at https://www.dosm.gov.my

Demographia (2017). 13th annual Demographia international housing affordability survey: 2017 rating middle-income housing affordability. Retrieved from www.demographia.com/dhi.pdf.

Khazanah Research Institute [KRI] (2015). The State of Household. Kuala Lumpur: Author.

Knight Frank (2015). Malaysian real estate highlights 2nd half 2015. Retrieved from https://www.knightfrank.com/publications/malaysia-real-estate-highlights2h2017-5210.aspx.

Loan criteria won't resolve affordable housing issue. (2017, July 19). The StarOnline. Retrieved from https://www.thestar.com.my/business/businessnews/2017/07/19/bank-negara-loan-criteria-review-wont-resolve-affordablehousing-issue/

National Property Information Centre [NAPIC] (2014). The Malaysian house price index by house type. Available at www.jpph.gov.my.

National Property Information Centre [NAPIC] (2014 - 2015). Property overhang. Available at http://napic.jpph.gov.my/portal

National Property Information Centre [NAPIC] (2015). Property market status report: 
Q4 year 2015 (Property Overhang Q4 2015). Available at www.jpph.gov.my.

National Property Information Centre [NAPIC] (2017). The Malaysian house price index increased by 5.3\% in Q1P 2017 relative to Q1 2016. Available at www.jpph.gov.my.

Olanrewaju, A., Tat, L. L., Tan, S. Y., Naoto, M., \& Abdul Aziz, A. (2016). Analysis of economic determinants of affordable housing price. In H. H. Lau, F. E. Tang, C. K. Ng, \& A. Singh (Eds.), Integrated solutions for infrastructure development (pp. 1-6).

Olanrewaju, A. \& Woon, T. C. (2017). An exploration of determinants of affordable housing choice. International Journal of Housing Markets and Analysis, 10(5), 703-723.

Olanrewaju, A., Tan, Y. S., Tat, L. L., \& Mine, N. (2017). Analysis of homeowners' behaviours in housing maintenance. Procedia Engineering, 180, 1622-1632.

Ong, S. T. \& Chang, S. Y (2013). Macroeconomic determinants of Malaysian housing market. Human and Social Science Research, 1(2), 119-127.

Osman, M. M., Bachok, S., Shuid, S., \& Khalid, N. (2017a) Factors influencing housing prices among local people: a study in Perak, Malaysia. Advanced Science Letters, 23(1), 165-168.

Osman, M. M., Muhamad Yusop, S. W., Shuid, S., \& Abdullah, M. F. (2017b). Housing affordability index for districts in Perak. Advanced Science Letters, 23(7), 60496052.

Osman, M. M., Rabe, N. S., Abdullah, M. F., Rosli, N. F., \& Zainudin, F. E. (2017c) Housing affordability in the state of Melaka. Planning Malaysia: Journal of the Malaysian Institute of Planners, 15(1), 255-260.

Osman, M. M., Ramlee, M. A., Samsudin, N., Rabe, N. S., Abdullah, M. F., \& Khalid, N. (2017d). Housing affordability in state of Johor. Planning Malaysia, 15(1), 347-356.

Pillaiyan, S. (2015). Macroeconomic drivers of house prices in Malaysia. Canadian Social Science, 11(9), 119-130.

Real Estate and Housing Developers' Association Malaysia [REHDA] (2016). MIER's residential property survey report $4 Q 2015$. Available at http://rehda.com/

UN-HABITAT (2011). Affordable Land and Housing in Asia. Nairobi: UNON, Publishing Services Section.

Ying, X. L., Olanrewaju, A., \& Tan, S.Y. (2015) Strategies for affordable housing delivery. Australian Journal of Basic and Applied Sciences, 9(25), 118-124. 